\title{
Silicate electrochemical measurements in seawater: Chemical and analytical aspects towards a reagentless sensor
}

\author{
Marielle Lacombe ${ }^{\mathrm{a},{ }^{*}}$, Véronique Garçon ${ }^{\mathrm{a},{ }^{*}}$, Danièle Thouron $^{\mathrm{a}}$, Nadine Le Bris ${ }^{\mathrm{b}}$ and Maurice \\ Comtat $^{\mathrm{C}}$
}

\footnotetext{
a Laboratoire d'Etudes en Géophysique et Océanographie Spatiales, Centre National de la Recherche Scientifique, UMR 5566, 18 Avenue Edouard Belin, 31401 Toulouse Cedex 9,France

b Ifremer, Département Etude des Ecosystèmes Profonds, BP70, 29280 Plouzané, France

c Laboratoire de Génie Chimique, UMR 5503, Université Paul Sabatier, 118 route de Narbonne, 31062 Toulouse Cedex, France
}

*: Corresponding author : Marielle Lacombe, email address : marielle.lacombe@obs-mip.fr, Véronique Garçon, email address : Veronique.Garcon@legos.obs-mip.fr

\begin{abstract}
:
From the study of molybdenum oxidation in aqueous solutions we developed a semi-autonomous method to detect silicate in aqueous samples. Molybdenum oxidation was used to form molybdate in acidic media. The silicomolybdic complex formed with silicate is detectable by amperometry or cyclic voltammetry. The new electrochemical method is in good agreement with the method conventionally used for environmental water silicate analysis. In the second stage, a completely reagentless method was developed using molybdate and proton produced during molybdenum oxidation. Reproducibility tests show a precision of $2.6 \%$ for a concentration of $100 \mu \mathrm{mol} \mathrm{L}^{-1}$. This new method will be very suitable for the development of new autonomous silicate sensors easy to handle and without reagents. In this paper we present the analytical and chemical aspects necessary for a complete documentation of the method before the development of a new reagentless sensor.
\end{abstract}

Keywords: Molybdenum; Silicate; Reagentless; Amperometry; Cyclic voltammetry 


\section{Introduction}

The common analytical technique to measure silicate in natural waters is the spectrophotochemical method. It involves the addition to the sample of an acidic molybdate solution to convert the silicate to a Keggin anion, $\mathrm{SiMo}_{12} \mathrm{O}_{40}{ }^{4-}$ and subsequent chemical reduction to a mixed oxidation state, a molybdenum complex which is intensely blue with a maximum of absorption at $810 \mathrm{~nm}$ [1]. This method is now frequently carried out in automated continuous flow systems [2], and in situ analyzers have been developed to measure nutrients autonomously in the ocean [3-6]. Selectivity between silicate and phosphate remains a significant problem because of their very similar chemical behaviour [7], and a systematic salt effect is present in automated nutrient determination in seawater [8]. Simultaneous determination of phosphate and silicate is possible by first-derivative spectrophotometry [9].

Silicate determination was also performed by ion exclusion chromatography with UV detection in leaching process waters [10] and in fresh water using flow injection with luminol chemiluminescence detection [11]. Recently a sorption-chromatographic method for determining phosphate and silicate ions in waters as molybdic heteropoly acids was developed [12]. Silicate was also measured in seawater by inductively coupled plasma atomic emission spectrometry [13], by ion exclusion chromatography with conductivity detection [14], by ion exclusion chromatography in combination with inductively coupled plasma-mass spectrometer [15].

Some electrochemical methods have been reported to measure silicate and phosphate using heteropolymolybdates [16-18]. The orthophosphate amperometric detection was investigated by flow injection analysis by Harden and Nonidez [19] and by batch injection analysis by Quintana et al. [20]. The amperometric detection was also used for phosphate 
determination with a bienzyme electrode [21]. Carpenter et al. [22] presented fundamental studies with ultra microelectrodes, for the determination of silicate and phosphate in water. Hodgson and Pletcher extended this study and discussed the ways to enhance selectivity between silicate and phosphate [23]. The response of the silicomolybdic complex was investigated by Lee and Gerwirth on silver and gold electrodes [24]. Finally, a differential pulse polarographic method was used to detect trace of phosphate in environmental samples $[25]$.

Some in situ voltammetric probes have already been developed for chemical monitoring and speciation $[26 ; 27]$. Electrochemistry allows to measure several species simultaneously with very good spatial and time resolutions, at low cost and very low concentrations, without reagents and therefore is a very promising method for the development of a small, precise and autonomous in situ sensor.

First steps towards the development of a reagentless method for silicate determination in seawater samples were presented in a previous paper [28]. This previous paper was the description of the seawater application of the method during the Drake ANT XXIII/3 oceanographic cruise by oxidizing molybdenum in a measurement cell and adding sulphuric acid. The comparison of the results of this method with those of the classical spectrophotometric one showed a very good agreement between both methods. The aim of the work here is to describe in details the chemical and electrochemical bases of this new method and to discuss its advantages and potential as compared to other methods. These aspects are necessary for the development of a new sensor. Experiments described here present a new step toward an autonomous sensor. We first present the method used to measure silicate and to describe the electrochemical behaviour of the silicomolybdic complex, then the study of the molybdenum oxidation and the development of the semi autonomous 
method. Finally a complete reagentless method for silicate detection is presented and we conclude by the discussion on this new method. 


\section{Experimental section}

\subsection{Apparatus}

Cyclic and linear sweep voltammetry and chrono-amperometry were carried out with a potentiostat $\mu$-Autolab III (Metrohm). The rotating disk electrode (RDE) was controlled by an RDE controller (Metrohm). Voltammograms at a stationary or rotating disk electrode were recorded in a three electrode cell with a carbon counter electrode. Working electrodes were in gold, platinum, or glassy carbon with an area of $0.07 \mathrm{~cm}^{2}$ (Metrohm). All potentials are given versus an $\mathrm{Ag} / \mathrm{AgCl}\left(\mathrm{KCl} 3 \mathrm{~mol}^{-\mathrm{L}^{-1}}\right)$ reference electrode. The glassy carbon disk was polished with lapping film sheet (3M Aluminium Oxide, 1 micron) before each measurement. Amperometry was made with a glassy carbon disk working electrode held at a constant potential of $200 \mathrm{mV}$.

The reference colorimetric analysis of silicate was performed according to Le Corre and Tréguer's method [29]. Laboratory colorimetric measurements were made with an AutoAnalyzer Technicon II (AAII, Bran Luebbe). On board colorimetric measurements were made with an Auto-Analyzer (Skalar).

$\mathrm{pH}$ measurements were made with a $744 \mathrm{pH}$ meter Metrohm calibrated with Bioblock buffered solutions.

\subsection{Reagents and solutions}


All solutions were prepared in Milli-Q water (Millipore Milli-Q water system) with reagent grade salts. Artificial seawater for standards calibration, silicate and phosphate samples, was prepared at a salinity of $34.7 \mathrm{~g} . \mathrm{L}^{-1}$, with $32.13 \mathrm{~g}$ of sodium chloride $(\mathrm{NaCl}), 7.13$ $\mathrm{g}$ of magnesium-sulfate heptahydrate $\left(\mathrm{MgSO}_{4}, 7 \mathrm{H}_{2} \mathrm{O}\right)$ and $0.17 \mathrm{~g}$ of sodium carbonate $\left(\mathrm{NaCO}_{3}\right)$, per liter of water.

Silicate standard solutions were prepared with sodium silicofluoride $\left(\mathrm{Na}_{2} \mathrm{SiF}_{6}\right.$, Merck) and potassium dihydrogen phosphate $\left(\mathrm{KH}_{2} \mathrm{PO}_{4}\right.$, Merck) (Gordon et al., 1993).

Solutions used for silicate and phosphate voltammetric measurements are sodium molybdate $10 \mathrm{mmol} . \mathrm{L}^{-1}\left(\mathrm{Na}_{2} \mathrm{MoO}_{4}, 2 \mathrm{H}_{2} \mathrm{O}\right)$ and sulphuric acid $\left(\mathrm{H}_{2} \mathrm{SO}_{4}, 5 \mathrm{~N}\right)$ to adjust the $\mathrm{pH}$ at 1.5 .

Reagents used for silicate spectrophotometric determinations are: an acidified ammonium heptamolybdate solution (10 $\mathrm{g}$ of ammonium heptamolybdate, $40 \mathrm{~mL}$ of sulphuric acid, $\mathrm{H}_{2} \mathrm{SO}_{4} 2,5 \mathrm{~mol} . \mathrm{L}^{-1}$ in $1000 \mathrm{~mL}$ of Milli-Q water); an oxalic acid solution (7 $\mathrm{g}$ of oxalic acid and $50 \mathrm{~mL} \mathrm{H}_{2} \mathrm{SO}_{4}$ in $1000 \mathrm{~mL}$ of Milli-Q water and $1 \mathrm{~mL}$ of Aerosol 22(Sigma)), an ascorbic acid solution (17.8 $\mathrm{g}$ of L-ascorbic acid and $25 \mathrm{~mL}$ of acetone in $1000 \mathrm{~mL}$ of Milli-Q water and $1 \mathrm{~mL}$ of Aerosol 22).

Spectrophotometric baseline measurements were made with artificial seawater. Standards solutions used on board were tested back in the laboratory with commercial standards (OSIL, $\left.1000 \mu \mathrm{mol} . \mathrm{L}^{-1}\right)$ and no difference was observed.

\subsection{Procedure}

Electrochemical measurements with addition of reagents were made in $100 \mathrm{~mL}$ of artificial seawater with sodium molybdate at $10 \mathrm{mmol} . \mathrm{L}^{-1}$ and the $\mathrm{pH}$ adjusted to 1.5 . 
Measurements were made after at least 6 minutes at $25^{\circ} \mathrm{C}$. For amperometric measurements a rotating disk electrode (1000 rpm) was used.

For the semi-autonomous method, molybdate was produced by molybdenum anodic oxidation. The molybdenum electrode (Good Fellow Metals, purity: $99.9 \%$ ) has an area of $1.2 \mathrm{~cm}^{2}$. The oxidation was performed at a constant electrolysis current (50 mA) during 420 seconds, in a $5 \mathrm{~mL}$ cell. $\mathrm{pH}$ was adjusted to 1.5 by addition of sulphuric acid $\mathrm{H}_{2} \mathrm{SO}_{4} 5$ mol.L $\mathrm{L}^{-1}$ [28].

For the reagentless method, a $6 \mathrm{~mL}$ cell divided in two by a porous polyethylene membrane was used. Molybdenum, reference and sensing electrodes were placed in the anodic compartment while the counter electrode was in the cathodic compartment. Molybdate was produced by molybdenum anodic oxidation performed at a constant electrolysis current (50 mA) during 360 seconds [28].

\subsection{Seawater collection}

The collection of seawater samples were made during the ANT XXIII/3 cruise aboard the R/V Polarstern during the austral summer 2006 from January $14^{\text {th }}$ to February $8^{\text {th }}$ between Punta Arenas (Chile) and the Antarctic Peninsula [28]. 


\section{Results and discussion}

\subsection{Electrode material}

As electronic exchanges are extremely dependent on the nature of the electrode material, we first evaluated the electroactivity domains of various materials in seawater. So we made voltammograms in seawater (at 34.7 g. $\mathrm{L}^{-1}$ and $\mathrm{pH}$ 8.2) on gold, silver, platinum, glassy carbon, tungsten, and molybdenum. Theses domains, represented on Figure 1, are limited by the reduction of water (Equation 1), its oxidation (Equation 2) or the oxidation of the metal for silver (Equation 3) and molybdenum (Equation 4 to Equation 6) for a current density $(j)$ of $0.710^{-3}$ A.cm ${ }^{-2}$.

Equation 1

Equation 2

Equation 3

Equation 4

Equation 5

Equation 6

$2 \mathrm{H}_{2} \mathrm{O}+2 \mathrm{e}^{-} \rightarrow \mathrm{H}_{2}+2 \mathrm{OH}^{-}$

$2 \mathrm{H}_{2} \mathrm{O} \rightarrow \mathrm{O}_{2}+4 \mathrm{H}^{+}+4 \mathrm{e}^{-}$

$$
\mathrm{Ag}+\mathrm{Cl}^{-} \rightarrow \mathrm{AgCl}+1 \mathrm{e}^{-}
$$

$$
\mathrm{Mo}+2 \mathrm{H}_{2} \mathrm{O} \rightarrow \mathrm{MoO}_{2}+4 \mathrm{H}^{+}+4 \mathrm{e}^{-}
$$

$$
\mathrm{Mo}+3 \mathrm{H}_{2} \mathrm{O} \rightarrow \mathrm{MoO}_{3}+6 \mathrm{H}^{+}+6 \mathrm{e}^{-}
$$




\subsection{Molybdosilicate complex}

Silicate are non electroactive species thus the voltammetric determination of this ion involves the treatment of the sample with an acidic molybdate solution to form a Keggin anion, $\mathrm{Si}\left(\mathrm{Mo}_{12} \mathrm{O}_{40}\right)^{4-}$ (Equation 7).

\section{Equation 7}

$$
\mathrm{Si}(\mathrm{OH})_{4}+12 \mathrm{MoO}_{4}{ }^{2-}+24 \mathrm{H}^{+} \rightarrow \mathrm{H}_{4} \mathrm{Si}\left(\mathrm{Mo}_{12} \mathrm{O}_{40}\right)+12 \mathrm{H}_{2} \mathrm{O}
$$

This complex shows two reduction waves on glassy carbon (Figure 2), platinum and gold. The voltammograms for the solution containing the molybdosilicate complex show the two well formed reduction peaks at about $350 \mathrm{mV}$ and $240 \mathrm{mV}$ and the two well formed oxidation peaks at $400 \mathrm{mV}$ and $290 \mathrm{mV}(\mathrm{vs} \mathrm{Ag} / \mathrm{AgCl})$. A linear correlation of the four peak intensities versus silicate concentration is observed between 0.3 and $145 \mu \mathrm{mol} . \mathrm{L}^{-1}$ [28]. Silver is unusable because of its reaction with chloride in seawater. Moreover it has been reported that the Keggion anion passivates the Ag surface towards solution redox events [24]. For commodity reasons all our experiments were made on glassy carbon electrode but they could have been made on platinum or gold materials. We chose to use a glassy carbon electrode to be able to compare results with the previous studies [28]. Moreover measurements on other materials need more investigations on the protocols of preparation of the surface electrodes in order to obtain reliable and reproducible results. 
The response of molybdate on glassy carbon electrode is shown on Figure 3 by consecutive linear sweep voltammograms at $50 \mathrm{mV} / \mathrm{s}$. The first peak at about $-200 \mathrm{mV}$ appears to be due to the oxygen reduction. The molybdate reduction is characterized by the second peak at $-410 \mathrm{mV}$. It increases with the number of scans if the electrode is not polished, while after polishing the voltammogram recovers its first appearance. This gradual increase of the peak intensity could be due to a molybdate polymerization at the electrode surface, doubling the number of electrons involved during the reduction [30].

At ambient temperature the complex is totally formed in less than 6 minutes. The very slow scan rate voltammogram $(5 \mathrm{mV} / \mathrm{s})$ with glassy carbon rotating disk electrode $(1000 \mathrm{rpm})$ on Figure 4 presents two reduction waves with half-wave potentials at $335 \mathrm{mV}$ for the first reduction and $246 \mathrm{mV}$ for the second reduction.

This stationary state voltammogram shows that the first reaction involves two electrons and the second reaction involves three electrons, in agreement with previous studies [31]. Thus the first reduction is the reduction of molybdenum (VI) in molybdenum (IV) and the second reaction is the reduction of molybdenum (IV) in molybdenum (I). Moreover the forward scan is similar to the backward scan indicating the absence of absorption and of chemical reaction of the complex during the time of the experiment.

Intensity potential curves obey the law described by Equation 8 indicating the irreversibility of the electron transfer [32]:

Equation 8: $\quad E=\frac{R T}{\alpha n F} \ln \frac{I_{0}}{I_{\lim }}+\frac{R T}{\alpha n F} \ln \frac{I_{\lim }-I}{I}$ 
with: $R=$ the gas constant $\left(8.314 \mathrm{~J} \cdot \mathrm{mol}^{-1} \cdot \mathrm{K}^{-1}\right), T=$ the absolute temperature (Kelvin), $F=$ the Faraday constant, $\alpha=$ the transfer coefficient, $I_{0}=$ the exchange current, and $I_{\text {lim }}=$ the limiting current.

We can deduce from Equation 8 the two cathodic transfer coefficients $(\alpha)$ to characterize the reaction rate. From the linearization of the curves a $\alpha_{1 c}$ coefficient equal of 0.5 is determined for reduction 1 and $\alpha_{2 c}=0.8$ for reduction 2 . Typical values of $\alpha$ are between 0.3 and 0.7 [32]. The high value of the transfer coefficient of $\alpha_{2 c}$ means that during the second reduction the electrons are transferred faster than normally.

\subsection{Temperature effect on the complexation rate}

As we developed this new method in order to build a new in situ sensor it is extremely important to know the impacts of temperature on the analytical response. In the different applications of the future sensor and particularly in the environmental applications temperature can vary from $0{ }^{\circ} \mathrm{C}$ to more than $25^{\circ} \mathrm{C}$. In the field of oceanography temperature measurement is a key parameter. The complexation process is expected to be strongly dependent on temperature. Its influence on the kinetics of molybdosilicate complexation (from 1.4 to $24.8{ }^{\circ} \mathrm{C}$ ) was quantified by measuring the intensity current of the first reduction peak as a function of time (Figure 5a). The rate constant is calculated by Equation 9:

$$
\text { Equation 9 : } \quad \ln \left(\frac{I_{\infty}}{I_{\infty}-I}\right)=k t
$$


With $t$ the time (s), $I_{\infty}=$ the current at $\mathrm{t} \rightarrow \infty$ (A), $I=$ the current (A) and $k$ the rate constant $\left(\mathrm{s}^{-1}\right)$

We thus determined the rate constant $k$ as a function of temperature (Figure $5 b$ ). According to the Arrhenius equation, an activation energy of about $54 \mathrm{~kJ} . \mathrm{mol}^{-1}$ was defined for the complexation reaction at $\mathrm{pH} 1.5$ from the slope of the plot represented in Figure $5 \mathrm{~b}$. This value will be useful to estimate the temperature sensitivity for a future silicate sensor.

\subsection{Amperometric response}

The working electrode held at a potential of $200 \mathrm{mV}$ to avoid its deterioration presents a linear response with silicate concentration (molybdate concentration of $10 \mathrm{mmol} . \mathrm{L}^{-1}$ at $\mathrm{pH}$ 1.5). This response is presented in Figure 6 with the working glassy carbon disk electrode rotating at $1000 \mathrm{rpm}$.

Previous studies have dealt with phosphate interferences and have suggested a method based on the differences of kinetics for the complexes formation [23; 28]. The molybdophosphate has a very fast response while molybdosilicate is longer to be formed.

This method presents the advantage to be very fast and easy to handle. A simple sensor could be adapted from this simple method.

\subsection{Molybdenum oxidation}

As the aim of this study was to develop an autonomous method we investigated the different ways to produce the silicomolybdic complex without reagent. We have first studied 
the molybdenum oxidation in different aqueous solutions $\left(\mathrm{H}_{2} \mathrm{SO}_{4} 0.5 \mathrm{~mol} . \mathrm{L}^{-1}, \mathrm{NaOH} 0.5\right.$ mol.L $\mathrm{L}^{-1}, \mathrm{H}_{2} \mathrm{SO}_{4} 0.5$ mol. $\mathrm{L}^{-1}+\mathrm{NaCl} 30 \mathrm{~g} . \mathrm{L}^{-1}$ and artificial seawater). The intensity potential curves are shown in Figure 7a. The anodic branches of the Tafel plots (Figure 7b) can be described by Equation 10 [32]:

Equation 10: $\quad \ln j=\ln j_{0}+\alpha n F R^{-1} T^{-1} \eta$

with $j=$ the current density $\left(\mathrm{A} . \mathrm{cm}^{-2}\right), j_{0}=$ the exchange current density $\left(\mathrm{A} . \mathrm{cm}^{-2}\right), \alpha=$ the anodic transfer coefficient, $\eta=$ the overpotential $(\mathrm{V}), F=$ the Faraday constant $\left(\mathrm{C}^{\mathrm{mol}}{ }^{-1}\right), n=$ the number of electrons and $R=$ the molar gas constant $\left(\mathrm{J} \cdot \mathrm{mol}^{-1} \cdot \mathrm{K}^{-1}\right)$.

The electrochemical oxidation of the molybdenum wire has been studied in alkaline and acidic media by Hull [33]. In both media the mechanism of the anodic dissolution proceeds through the formation of $\mathrm{Mo}(\mathrm{III})$ at low overvoltages and $\mathrm{Mo}(\mathrm{V})$ at higher values.

Impedance measurements of the anodic behaviour of Mo in alkaline media has been performed by Armstrong et al. [34] and showed that each new type of film had a valence state between III and VI. Bojinov et al. [35; 36] then investigated the transpassivity of molybdenum in $\mathrm{H}_{2} \mathrm{SO}_{4}$ solution. The polarization curves of molybdenum in $\mathrm{H}_{2} \mathrm{SO}_{4} 0.5$ mol. $\mathrm{L}^{-1}$ can be divided in three regions: the first Tafel region where the logarithm of the current varies linearly with potential E; the transition region where a pronounced curvature is observed in the $\log$ i-E curves and the second Tafel region (above $0 \mathrm{~V}$ ) where the current increases slowly with potential [35]. The Tafel plot slope is 20.5 and the exchange current density is $10^{-9.3} \mathrm{~A} \cdot \mathrm{cm}^{-2}$. It is assumed that, at open circuit, the Mo is almost completely 
covered with Mo(III) species (either a chemisorbed layer or a thin oxide-hydroxide film) which is oxidized to Mo(IV). At small positive overpotentials there is a continuous increase in the formal coverage of $\mathrm{Mo}(\mathrm{IV})$. At potentials of $-0.2 \mathrm{~V}$ and above, further oxidation of $\mathrm{Mo}(\mathrm{IV})$ to $\mathrm{Mo}(\mathrm{V})$ begins. At potentials close to $-0.1 \mathrm{~V}$, the coverage of $\mathrm{Mo}(\mathrm{V})$ reaches a maximum to form Mo (VI) in solution [35-37]. Molybdate in aqueous acidic solution is in equilibrium with hepta-molybdate and octa-molybdate according to Equation 11 and Equation 12. It was found that the dominant species was $\mathrm{MoO}_{4}{ }^{2-}$ in the $\mathrm{pH}$ range 7-12 and the protonated species were $\mathrm{Mo}_{7} \mathrm{O}_{24}{ }^{6-}$ and $\mathrm{Mo}_{8} \mathrm{O}_{26}{ }^{4-}$ in the $\mathrm{pH}$ range 3-5 and below $\mathrm{pH} \mathrm{2,}$ respectively $[30 ; 38 ; 39]$.

Equation 11

Equation 12

$$
7 \mathrm{MoO}_{4}{ }^{2-}+8 \mathrm{H}^{+} \leftrightarrow \mathrm{Mo}_{7} \mathrm{O}_{24}{ }^{6-}+4 \mathrm{H}_{2} \mathrm{O}
$$

$$
8 \mathrm{MoO}_{4}{ }^{2-}+12 \mathrm{H}^{+} \leftrightarrow \mathrm{Mo}_{8} \mathrm{O}_{26}{ }^{6-}+6 \mathrm{H}_{2} \mathrm{O}
$$

In alkaline media the anodic waves correspond to the formation of molybdenum (III), (IV) and (VI), oxide or hydroxide species. The Tafel plot slope is 1.7 and the exchange current density is $10^{-2.3} \mathrm{~A} . \mathrm{cm}^{-2}$. In artificial seawater we determined the Tafel plot slope at 8.1 and the exchange current density at $10^{-4.9}$ A.cm ${ }^{-2}$. It is of the same order of magnitude than those obtained for molybdenum oxidation in several media [38; 40]. Using Equation 10 we determine the factor $\alpha . n$, equal to 0.63 . Molybdenum oxidation in acidic media and sodium chloride 30 g. $\mathrm{L}^{-1}$ is very similar to molybdenum oxidation in artificial seawater.

\subsection{Semi-autonomous silicate method}


A semi-autonomous method for silicate detection has been developed based on the electrochemical anodic oxidation of molybdenum, the complexation of the oxidation product with silicate and the detection of the complex by cyclic voltammetry. Molybdate is produced in a small electrochemical cell with the addition of sulphuric acid to $\mathrm{pH} 1.5$. The quantity of molybdate formed is then controlled by a constant current intensity of $50 \mathrm{~mA}$ imposed to the molybdenum electrode. The theoretical charge necessary to form molybdate in large excess is given by the Faraday law (Equation 13). Different oxidation times were used measuring the kinetics of the reaction and the molybdenum oxidation of 420 seconds corresponding to a concentration of $7.3 \mathrm{mM}$ presented a higher limiting current $(2.5 \mu \mathrm{A})$.

Equation 13: $\quad$ Q $=$ n F.V.C $=$ I.t

with $Q=$ the electricity quantity (Coulombs), $V=$ the volume $\left(\mathrm{cm}^{3}\right), C=$ the molybdate concentration $\left(\mathrm{mol} . \mathrm{cm}^{-3}\right), I=$ the intensity $(\mathrm{A})$ and $t=$ the time $(\mathrm{s})$.

This method was tested and compared with the classical colorimetric one on real marine samples during the ANT XXIII/3 cruise across Drake Passage (January-February 2006). The detection limit is $1 \mu$ mol. $\mathrm{L}^{-1}$ and the deviation between both methods is less than $3 \%$ for concentrations higher than $10 \mu \mathrm{mol} . \mathrm{L}^{-1}$ [28]. Typical vertical profile (depth versus silicate concentration) obtained in Drake Passage, demonstrates that our electrochemical method is in good agreement with the spectrophotometric flux injection analysis conventionally used for seawater silicate analysis [28].

\subsection{Reagentless method}


The semi-autonomous method required to acidify the solution to a $\mathrm{pH}$ of about 1.5. The molybdenum oxidation liberates protons in the reaction cell (Equation 6) and provides an alternative solution to the addition of acid [28]. To prevent the subsequent reduction of the proton formed at the cathode, the anode was separated from the cathode by a polyethylene diaphragm. The $\mathrm{pH}$ obtained in the anode cell (1.5) after 360 seconds of oxidation was close to the theoretical pH (1.1) calculated using Equation 6 and Equation 13 while in the cathode cell it was of about 10.6. The molybdosilicate complexation after 360 seconds of molybdenum oxidation is completely formed within 15 minutes at $19{ }^{\circ} \mathrm{C}$. Reproducibility tests show a precision of $2.6 \%$ for a concentration of $100 \mu$ mol. $L^{-1}$ [28]. Figure 8 shows the evolution of the molybdate peaks in the reaction cell as a function of the molybdenum oxidation time and $\mathrm{pH}$. In the negative currents, the first peak is due to the oxygen reduction (at about $-100 \mathrm{mV}$ ) while the second $(-500 \mathrm{mV})$ is the molybdate reduction, consistently with previous studies [30]. The increase of the peak intensity is clearly only due to the increase of the molybdate concentration. 


\section{Conclusions}

The electrochemical study of molybdenum oxidation and complexation by silicate ions in several aqueous solutions enabled us to build a semi-autonomous method for silicate detection using voltammetry. This new method that only requires to acidify the sample to $\mathrm{pH} 1.5$ was tested on seawater samples during the Drake ANTIII/3 cruise and compared with the classical spectrophotometric flux analysis. This electrochemical method is in good agreement with the method conventionally used for environmental water silicate analysis. In this article, we have also presented an upgraded method which is completely reagentless. This latter method using molybdate and protons produced during molybdenum oxidation should be very useful for developing a new reagentless sensor suitable for measurements in several environments where the use of reagent such as sulphuric acid is dangerous or impossible. This new method needs about 12 minutes to be completed but the time can be easily shortened to about 7 minutes by the reduction of the volume of the measurement cell or the increase of the intensity of the molybdenum. The limit of detection is less than $1 \mu \mathrm{mol} . \mathrm{L}^{-1}$ with the oxidation of molybdenum, thus this value is high compared to the colorimetric method (about 0.04 $\mu$ mol. $\mathrm{L}^{-1}$ ) [41]. But this detection limit is about $0.3 \mu \mathrm{mol} . \mathrm{L}^{-1}$ without oxidation thus this limit can be reduced with a better optimization of the oxidation step [28]. As the detection is fast and easy we can consider a sensor with several measurement cells in parallel with various detection electrodes to reduce the time of analysis in the laboratory or to increase the time resolution of the in situ measurement. One of the main advantages of this method compared to the classical spectrophotometric measurements is of course the absence of reagent reducing the weight, the size and increasing the autonomy of the future sensor. The power required is also reduced by using an electrochemical detection without reagent (and thus without pumps). Comparing with the in situ spectrophotometric analysers that already exist [3-6] the size of 
the future sensor will be considerably reduced (less than $3 \mathrm{Kg}$ ). This sensor will be easily adaptable on different platforms (particularly moorings, gliders or floats in the oceanographic field) and the low cost of the analysis will allow the multiplication of the sensors to increase the spatial resolution of silicate data. Electrochemistry will provide a small sensor suitable for long term in situ deployments (on oceanic biogeochemical observatories or in process imposing no human intervention for instance). 


\section{Acknowledgments}

We are grateful to Hélène Durliat from the Laboratoire de Génie Chimique (UMR 5503, University Paul Sabatier) for her very useful contribution. We thank the officers, scientists and crew of Drake ANT XXIII/3 cruise aboard R/V FS Polarstern for their invaluable assistance in the collection of data set and particularly Christine Provost the cruise Principal Investigator. M. L. was supported by a $\mathrm{PhD}$ grant from CNRS and IFREMER. 


\section{References}

[1] A. Aminot, R. Kérouel, Hydrologie des systèmes marins, paramètres et analyses. F. Ifremer(Eds.), 2004, pp. 336.

[2] V.W. Truesdale, C.J. Smith, Analyst, 101 (1976) 19.

[3] R. Vuillemin, D. Thouron, G. Gallou, L. Pares, B. Brient, A. Dubreule, V. Garçon, Sea Technol., 40 (1999) 75.

[4] D. Thouron, R. Vuillemin, X. Philippon, A. Lourenco, C. Provost, A. Cruzado, V. Garçon, Anal. Chem., 75 (2003) 2601.

[5] T. Gamo, H. Sakai, E. Nakayama, K. Ishida, H. Kimoto, Anal. Sci., 10 (1994) 843.

[6] K.S. Johnson, C.L. Beehler, C.M. Sakamoto-Arnold, Anal. Chim. Acta, 179 (1986a) 245.

[7] C. Neal, M. Neal, H. Wickham, Sci. Total Environ., 251-252 (2000) 511.

[8] B.M. Stewart, P.A.W. Elliott, Water Res., 30 (1996) 869.

[9] A. Youssef El-Sayed, Y.Z. Hussein, M.A. Mohammed, Analyst, 126 (2001) 1810.

[10] M. Ikedo, M. Mori, K. Kazumasa, W. Hu, K. Tanaka, Anal. Sci., 22 (2006) 117.

[11] M. Yaqoob, A. Nabi, P.J. Worsfold, Anal. Chim. Acta, 519 (2004) 137.

[12] A.V. Medvetskii, T.I. Tikhomirova, A.D. Smolenkov, E.N. Shapovalova, O.A. Shpigun, J. Anal. Chem., 62 (2007) 213.

[13] K. Abe, Y. Watanabe, J. Oceanogr., 48 (1992) 283.

[14] H. Li, F. Chen, J. Chromatogr., A, 874 (2000) 143.

[15] A. Hioki, J. Lam, J. McLaren, Anal. Chem., 69 (1997) 21. 
[16] W. Er-Kang, W. Meng-Xia, Anal. Chim. Acta, 144 (1982) 147.

[17] A.G. Fogg, N.K. Bsebsu, B.J. Birch, Talanta, 28 (1981) 473.

[18] K. Matsunaga, I. Kudo, M. Yanada, K. Hasebe, Anal. Chim. Acta, 185 (1986) 355.

[19] S.M. Harden, W.K. Nonidez, Anal. Chem., 56 (1984) 2218.

[20] J.C. Quintana, L. Idrissi, G. Palleschi, P. Albertano, A. Amine, M. El Rhazi, D. Moscone, Talanta, 63 (2004) 567.

[21] S. Cosnier, C. Gondran, J. Watelet, W. De Giovani, R. Furriel, F. Leone, Anal. Chem., 70 (1998) 3952.

[22] N.G. Carpenter, A.W.E. Hodgson, D. Pletcher, Electroanalysis, 9 (1997bis) 1311.

[23] A.W.E. Hodgson, D. Pletcher, Electroanalysis, 10 (1998) 321.

[24] L. Lee, A.A. Gewirth, J. Electroanal. Chem., 522 (2002) 11.

[25] P. Sharma, K. Gehlot, S. Songara, Rev. Anal. Chem., 25 (2006) 140.

[26] G.W. Luther, T.F. Rozan, M. Taillefert, D.B. Nuzzio, C. Di Meo, T.M. Shank, R.A. Lutz, S.C. Cary, Nature, 410 (2001) 813.

[27] M. Tercier-Waeber, F. Confalonieri, G. Riccardi, A. Sina, S. Noel, J. Buffle, F. Graziottin, Mar. Chem., 97 (2005) 216.

[28] M. Lacombe, V. Garçon, M. Comtat, L. Oriol, J. Sudre, D. Thouron, N. LeBris, C. Provost, Mar. Chem., 106 (2007) 489.

[29] P. Le Corre, P. Tréguer. Contribution à l'étude de la matière organique dissoute et des sels nutritifs dans l'eau de mer. Caractéristiques physiques du Golfe de Gascogne et des upwellings côtiers de l'Afrique du Nord Ouest. Université de Bretagne Occidentale, Brest. 1976. 
[30] C.V. Krishnan, M. Garnett, B. Hsiao, B. Chu, Int. J. Electrochem. Sci., 2 (2007) 29.

[31] N.G. Carpenter, A.W.E. Hodgson, D. Pletcher, Electroanalysis, 9 (1997) 1311.

[32] A.J. Bard, Faulkner, L R,, Electrochemical methods: Fundamentals and Applications, second edition. Wiley J. and Sons (Eds.), 2001, pp. 833.

[33] M.N. Hull, J. Electroanal. Chem., 38 (1972) 143.

[34] R. Armstrong, M. Bell, A.A. Metcalfe, J. Electroanal. Chem. 84 (1977) 61.

[35] M. Bojinov, I. Betova, R. Raicheff, J. Electroanal. Chem., 381 (1995) 123.

[36] M. Bojinov, I. Betova, R. Raicheff, Electrochim. Acta, 41 (1996) 1173.

[37] M. Itagaki, T. Suzuki, K. Watanabe, Electrochim. Acta, 42 (1997) 1081.

[38] K. Wang, L. Ying-Sing, P. He, Electrochim. Acta, 43 (1998) 2459.

[39] J.J. Cruywagen, J.B.B. Heyns, Inorg. Chem., 26 (1987) 2569.

[40] L. De Rosa, C.R. Tomachuk, J. Springer, D.B. Mitton, S. Saiello, F. Bellucci, Mater. Corros., 55 (2004) 602.

[41] A. Aminot, R. Kérouel, Dosage automatique des nutriments dans les eaux marines. F. Ifremer (Eds.), 2007, pp 188. 


\section{Figure captions}

Figure 1: Electroactivity domains of molybdenum, tungsten, nickel, platinum, silver gold and glassy carbon electrodes in seawater ( $\mathrm{pH} 8.1)$.

Figure 2: (a) Voltammograms with $\mathrm{Si}(\mathrm{OH})_{4}=10 \mu \mathrm{mol} . \mathrm{L}^{-1}$ (grey line) and $120 \mu \mathrm{mol} . \mathrm{L}^{-1}$ (black line); sodium molybdate $=10 \mathrm{mmol} . \mathrm{L}^{-1}, \mathrm{pH} 1.5$, scan rate $=200 \mathrm{mV} / \mathrm{s}$ with vitreous carbon working electrode and $\mathrm{Ag} / \mathrm{AgCl}$ reference electrode. (b) Calibrations for concentrations from $0.3 \mu$ mol. $\mathrm{L}^{-1}$ to $145 \mu$ mol. $\mathrm{L}^{-1}$, obtained by the two oxidation and two reduction peaks.

Figure 3: Linear sweep voltammograms on glassy carbon electrode at $50 \mathrm{mV} / \mathrm{s}$ and $\mathrm{pH}$ 1.5: first, second and third consecutive voltammograms in seawater + sodium molybdate at 10 mmol. $\mathrm{L}^{-1}$ and voltammogram in seawater +sodium molybdate at $10 \mathrm{mmol} . \mathrm{L}^{-1}$ after polishing of the electrode.

Figure 4: Steady state voltammogram $(5 \mathrm{mV} / \mathrm{s})$ with glassy carbon rotating disk electrode $(1000 \mathrm{rpm})$ in artificial sea water, $100 \mu \mathrm{mol} . \mathrm{L}^{-1}$ of $\mathrm{Si}(\mathrm{OH})_{4}$, sodium molybdate $=10 \mathrm{mmol} . \mathrm{L}^{-}$ ${ }^{1}, \mathrm{pH} 1.5$.

Figure 5: (a) Kinetics of molybdosilicate complexation at different temperatures $(1.4,4.2$, 9.0, 14.6, 19.8 and $24.8^{\circ} \mathrm{C}$ ) by measuring the intensity current of the first reduction peak as a function of time, $\mathrm{Si}(\mathrm{OH})_{4}=170 \mu \mathrm{mol} . \mathrm{L}^{-1}$, sodium molybdate $=10 \mathrm{mmol} . \mathrm{L}^{-1}, \mathrm{pH} 1.5$; (b) $\mathrm{Ln}$ $(k)=\mathrm{f}(1 / T(\mathrm{~K}))$ corresponding plot to calculate the activation energy $E_{A}$.

Figure 6: (a) Chronoamperometric measurements at a glassy carbon rotating disk electrode (at $200 \mathrm{mV}$ ) for different silicate concentrations (10, 30, 56, 90, 122 and 155 $\mu$ mol. $\mathrm{L}^{-1}$ ), sodium molybdate $=10 \mathrm{mmol} . \mathrm{L}^{-1}, \mathrm{pH} 1.5$ and (b) corresponding calibration plot. 
Figure 7: (a) Linear sweep voltammograms $(1 \mathrm{mV} / \mathrm{s})$ for molybdenum oxidation in artificial seawater at $\mathrm{pH} 8.2$, sulphuric acid 0.5 mol. $\mathrm{L}^{-1}$, sodium chloride $30 \mathrm{~g} . \mathrm{L}^{-1}$ in sulphuric acid 0.5 mol. $\mathrm{L}^{-1}$ at $\mathrm{pH} 1.5$ and sodium hydroxide $0.5 \mathrm{~mol} . \mathrm{L}^{-1}$; (b) corresponding Tafel plots.

Figure 8: Monitoring of $\mathrm{pH}$ and molybdenum oxidation versus time during the reagentless method: voltammograms obtained in the reaction cell (near the anode) at 200 $\mathrm{mV} / \mathrm{s}$ on glassy carbon electrode at several time intervals of Mo oxidation. 
Figure 1

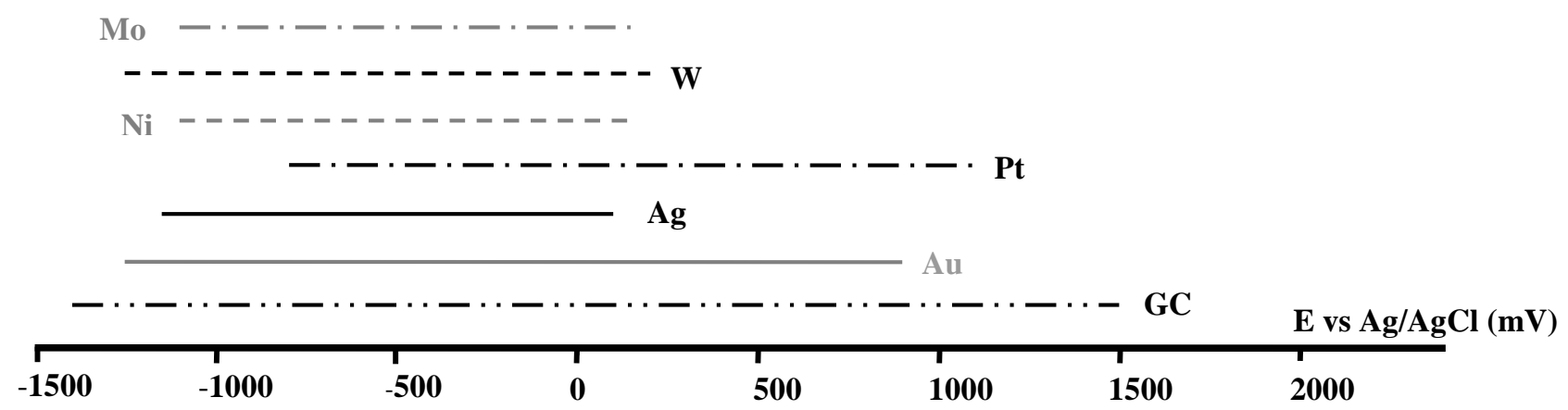


Figure 2

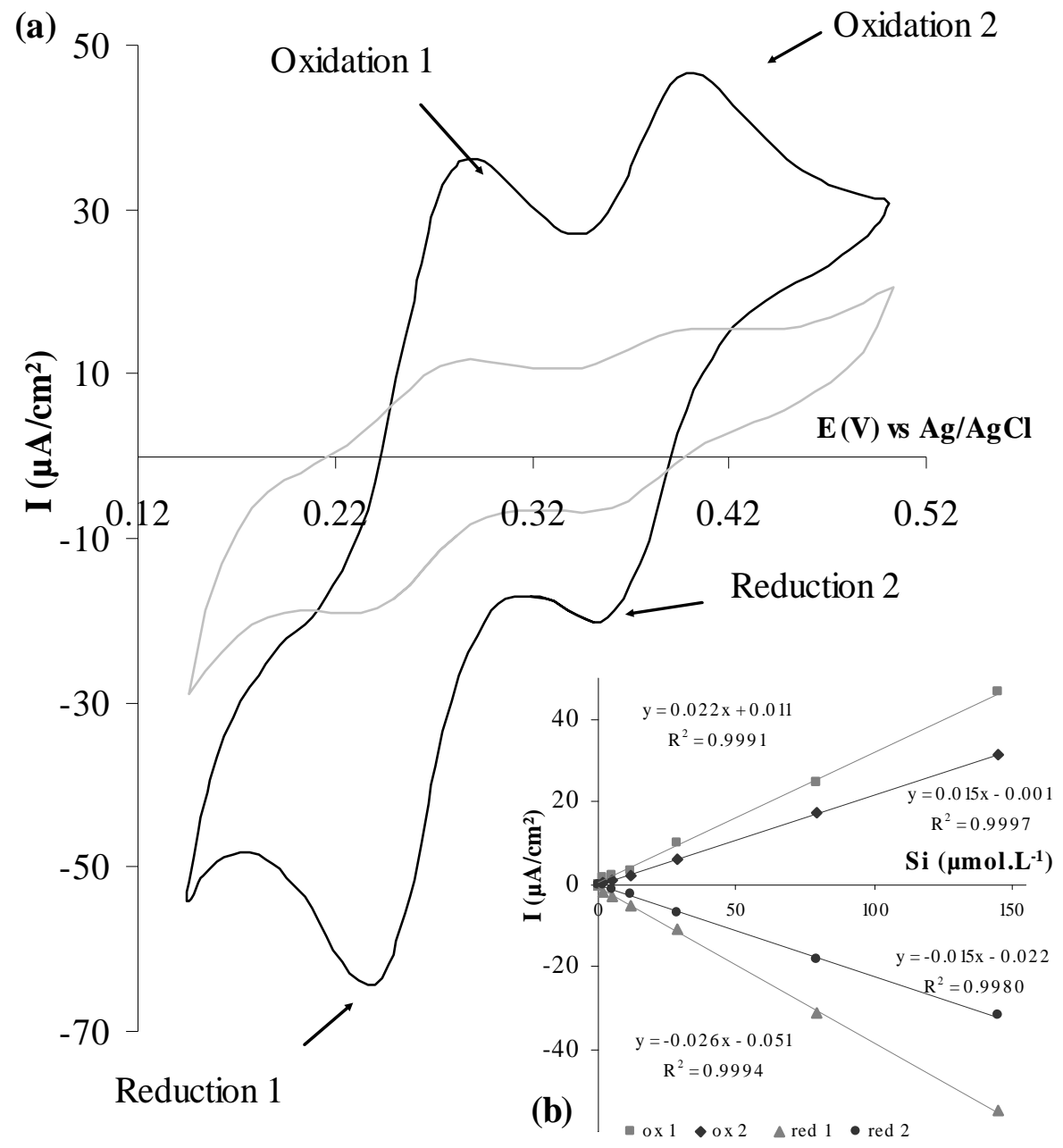


Figure 3

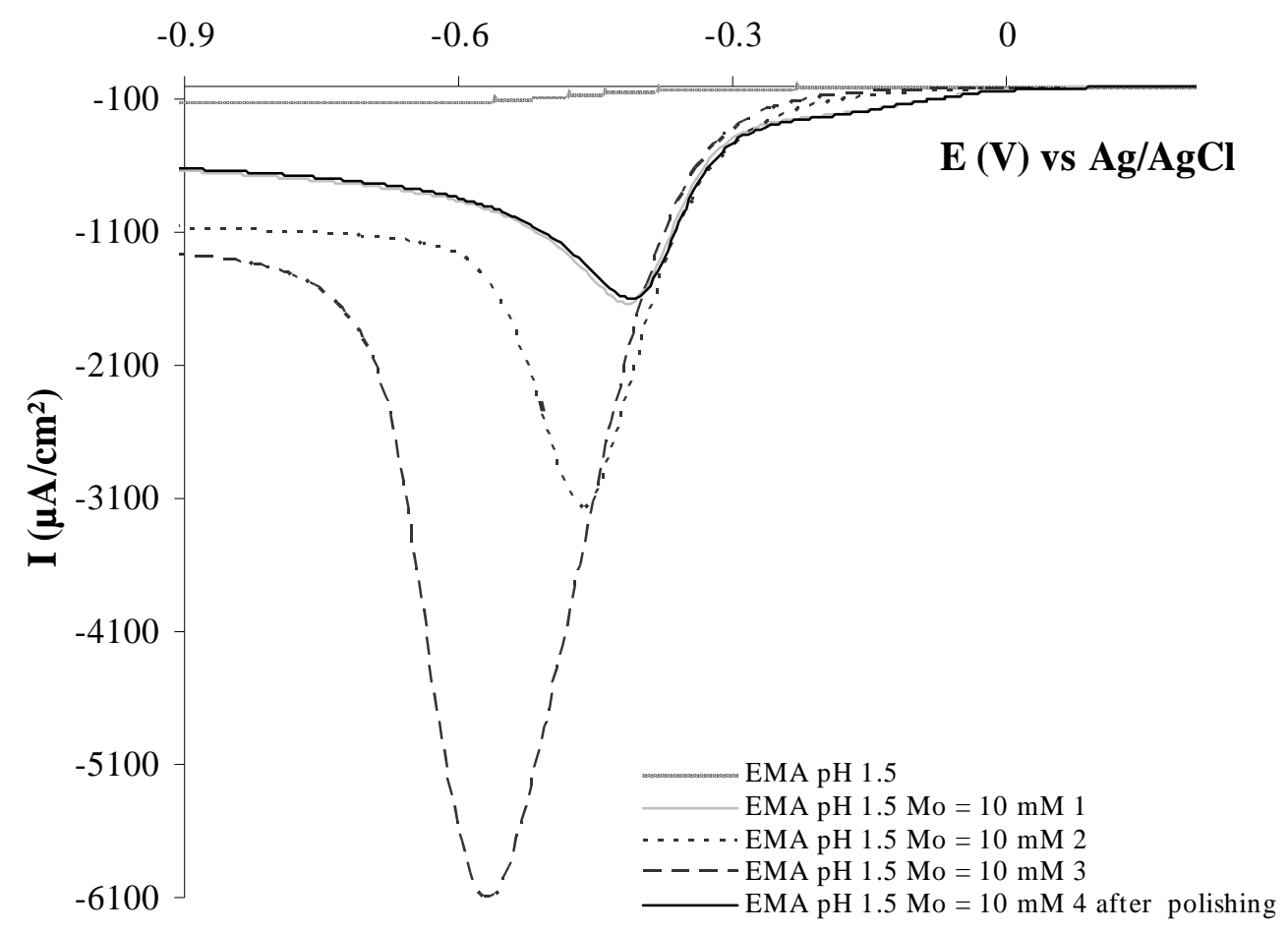


Figure 4

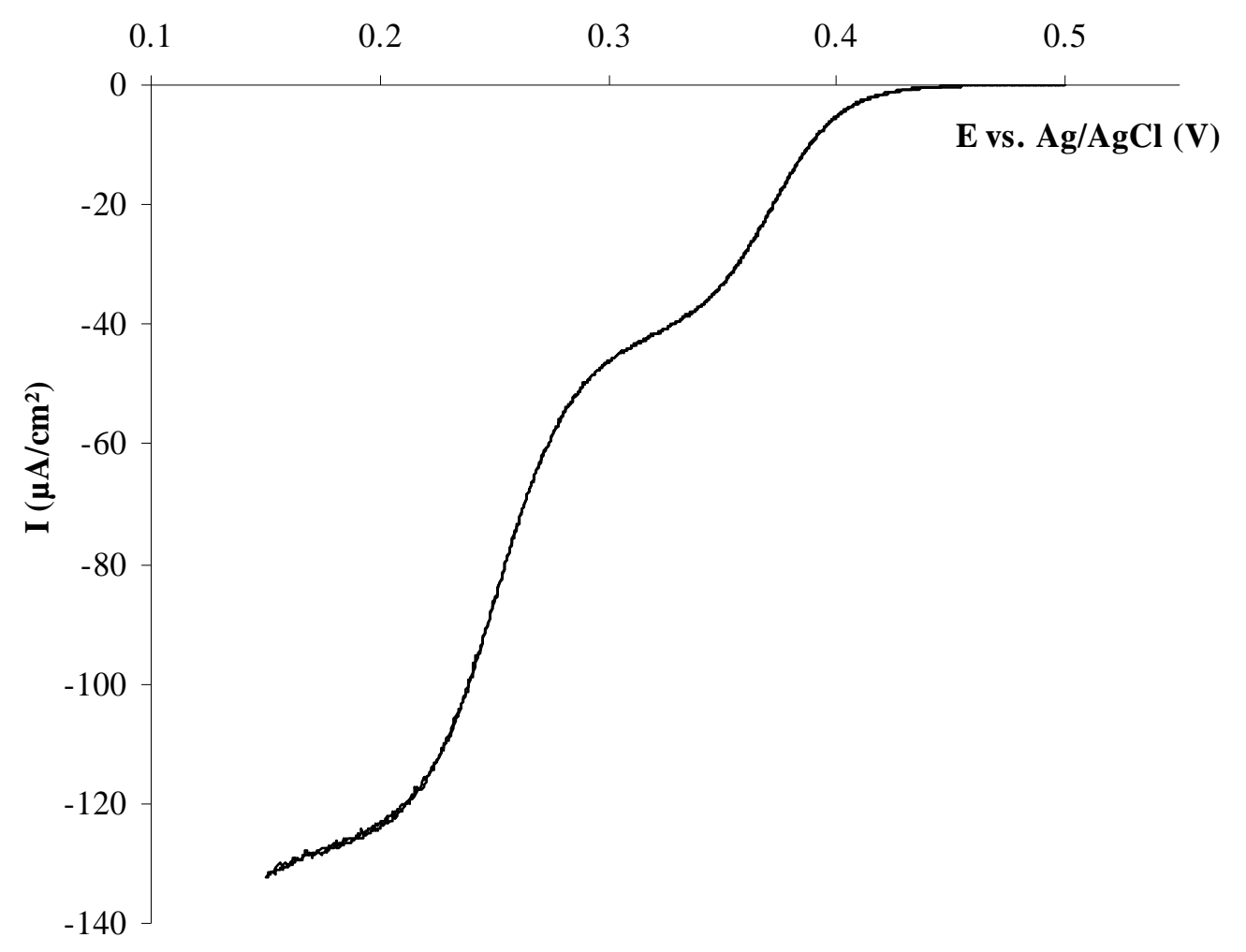


Figure 5

(a)
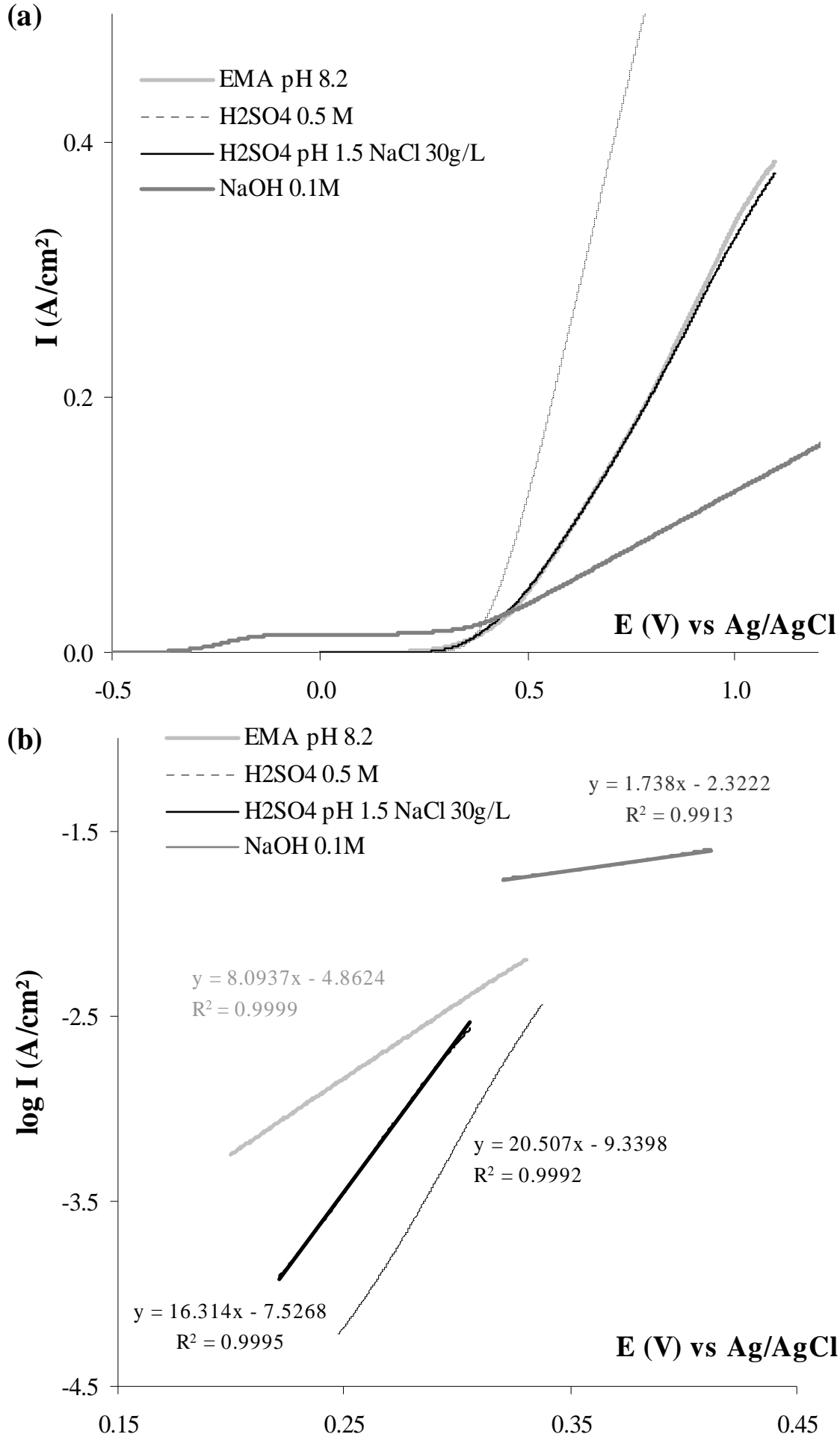
Figure 6

(a)

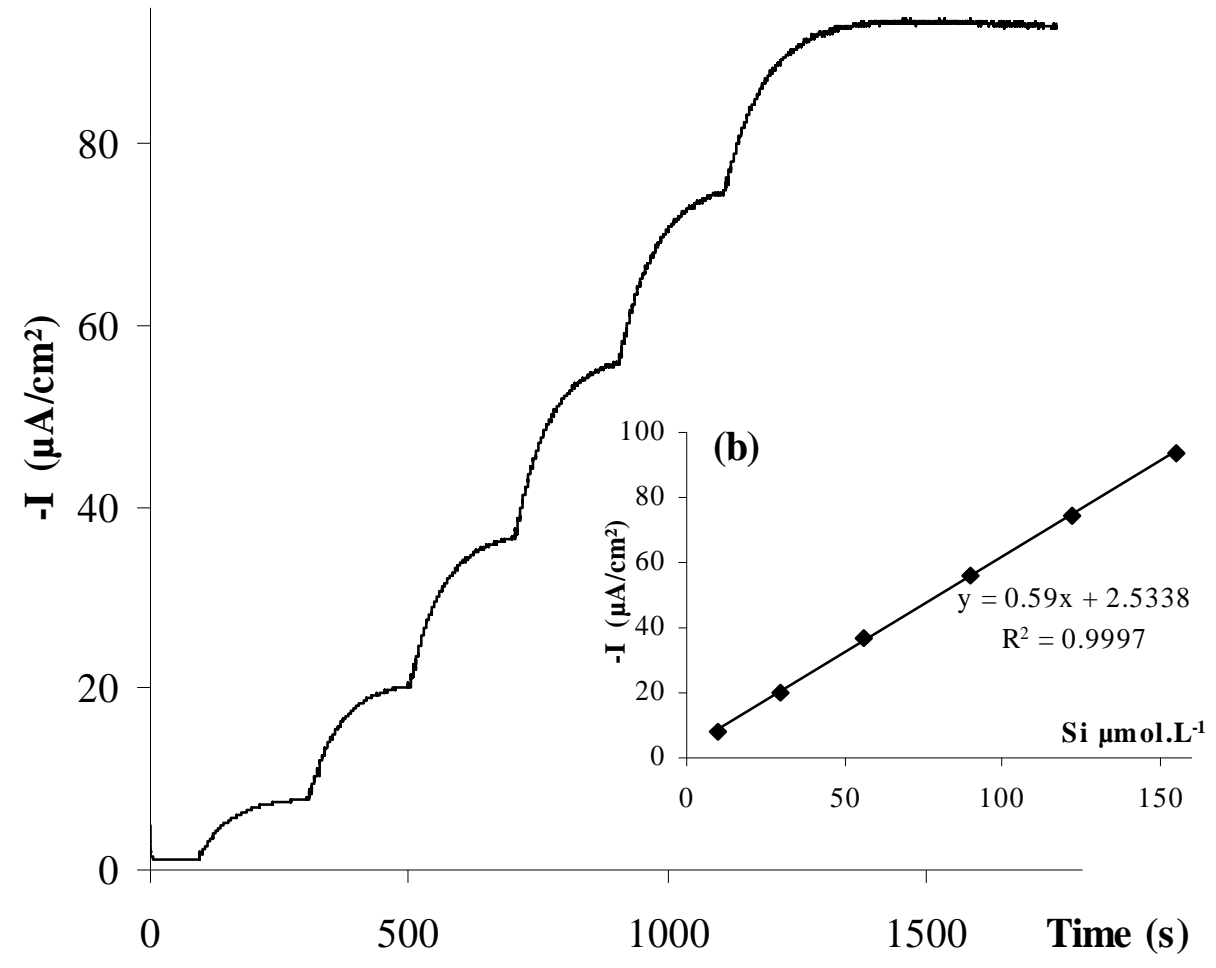


Figure 7

(a)
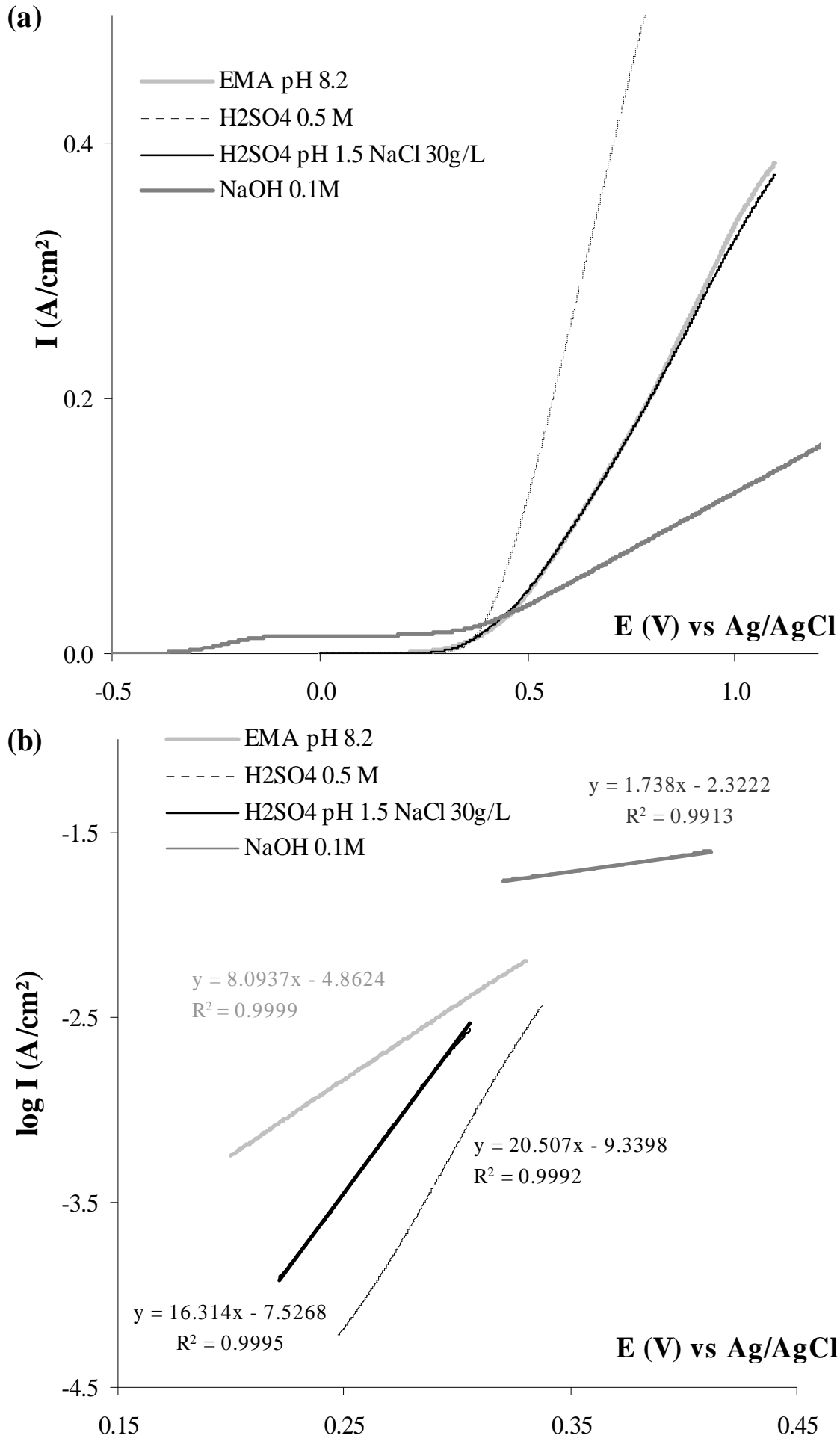
Figure 8

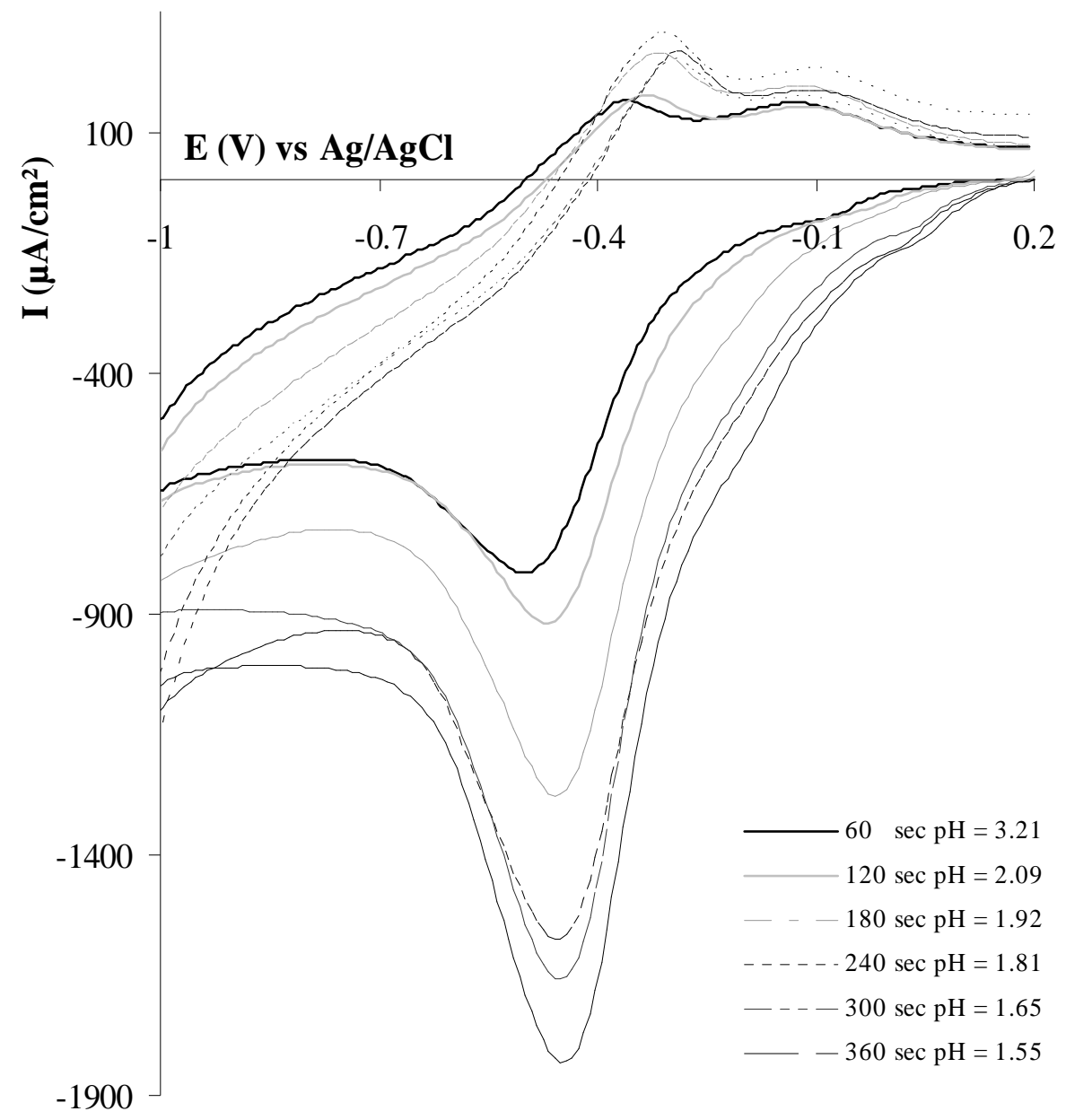

